In Vivo and In Vitro Effects of Staurosporine on the DNA Distributions in and Proliferation of Various Rodent Cell Populations

J. M. Kim

D. Archuleta

N. M. Lehnert

H. Crissman

L. R. Gurley

E. M. Bradbury

B. E. Lehnert

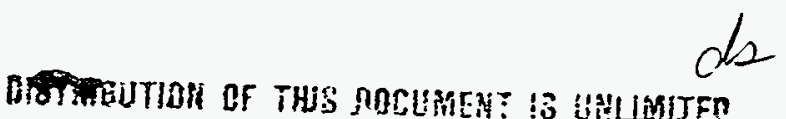




\section{DISCLAIMER}

This report was prepared as an account of work sponsored by an agency of the United States Government. Neither the United States Government nor any agency thereof, nor any of their employees, make any warranty, express or implied, or assumes any legal liability or responsibility for the accuracy, completeness, or usefulness of any information, apparatus, product, or process disclosed, or represents that its use would not infringe privately owned rights. Reference herein to any specific commercial product, process, or service by trade name, trademark, manufacturer, or otherwise does not necessarily constitute or imply its endorsement, recommendation, or favoring by the United States Government or any agency thereof. The views and opinions of authors expressed herein do not necessarily state or reflect those of the United States Government or any agency thereof. 


\section{DISCLAIMER}

Portions of this document may be illegible in electronic image products. Images are produced from the best available original document. 


\title{
In Vivo and In Vitro Effects of Staurosporine on the DNA Distributions in and Proliferation of Various Rodent Cell Populations
}

by

\author{
J.M. Kim, D. Archuleta, N.M. Lehnert, H. Crissman, \\ L.R. Gurley, E.M. Bradbury, and B.E. Lehnert
}

\begin{abstract}
Staurosporine (STSP), a protein kinase inhibitor, can reversibly arrest the proliferation of nontransformed cells in G1 of the cell cycle in vitro at low concentrations $(1 \mathrm{ng} / \mathrm{mL})$, whereas much higher concentrations of STSP $(75-100 \mathrm{ng} / \mathrm{mL})$ are required to arrest transformed cells. Such findings suggest that STSP might be pharmacologically useful to spare normal cells during some types of cancer therapy that preferentially target cycling cells. Given this possibility, we set out to examine the usefulness of STSP in bringing about a state of G1 arrest in vivo using rats and mice as experimental models. The first study series (I) focused on the effects of STSP on the distribution of DNA in bone marrow cells harvested from rats after intravenous (i.v.) bolus injections of STSP followed by continuous i.v. infusion of the drug. The i.v. route for administering STSP in these studies was based on the assumption that a continuous concentration of STSP, i.e., $1 \mathrm{ng} / \mathrm{mL}$, at tissue sites of interest would likely be required over an extended period to bring about a state of G1 arrest in normal cells. In a second study series (II), the duration of STSP treatment ranged from 48-120 hrs, and, in addition to bone marrow cells, alveolar macrophages, thymocytes, and splenocytes were examined for evidence of STSP-induced G1 arrest. The DNA distributions in cells studied during these two series of studies were analyzed by flow cytometry. STSP dose regimens used in the I and II study series were based on a pharmacokinetic model, but because inherent variables such as the apparent volume of distribution of STSP administered via the i.v. route and the elimination rate(s) of STSP from the blood compartment and other body sites were unknown, these experiments were performed by trial and analysis using arbitrarily imposed values for these variables. Data obtained from studies I and II indicated no response to the STSP treatment in the rat target cell populations examined. In a third study series (III), the effects of STSP on the proliferation of rat femur bone marrow (BM) cells and alveolar macrophages (AM) were examined in vitro to confirm that STSP can inhibit the proliferation of rat cells. The results from this study: 1) verified that the target cells are indeed inhibited from proliferating in the presence of STSP at very low concentrations (1-10 $\mathrm{ng} / \mathrm{mL}$ ), 2) established the possibility of producing a state of $\mathrm{Gl}$ arrest and anti-proliferation of the target cells in vivo if the dosimetry for the drug to target cells could be appropriately regulated, and 3) suggested that the failure to bring about a condition of G1 arrest in vivo in our previous studies may have been primarily due to the delivery of inappropriate concentrations of STSP to target cell compartments in the body. A fourth study series (IV) focused on the effects of STSP on the proliferative status of cells in the duodenums of the gastro-intestinal (GI) tracts of mice. The routes of STSP delivery in this study component consisted of daily intraperitoneal (i.p.) injections or STSP incorporated into food. Bromodeoxyuridine was administered to the animals to label proliferating cells. No reproducible STSP effects were observed. In a fifth study series (V), newly obtained pharmacokinetic data for STSP administered intravascularly was incorporated into the pharmacokinetic model employed in the first set of experiments (I and II) in order to further refine the dosimetry of STSP, and an initial set of experiments was performed with rats using the new dosing strategy. In this study, DNA distributions in alveolar macrophages, thymocytes, and bone marrow cells were examined by flow cytometry as in the I and II study series. Again, no antiproliferative effects of STSP were observed.
\end{abstract}




\section{Introduction}

Staurosporine (STSP) is a metabolic alkaloid produced by a strain of Streptomyces $S p$. (Omura et al., 1977). STSP has been found to be a broad protein kinase inhibitor, including protein kinase C (PKC) (Tamaoki et al., 1986), cGMP-dependent protein kinase (Niggli and Keller, 1991), cAMP-dependent protein kinase (Morioka et al., 1985), myosin light-chain kinase (Furukawa et al., 1989), and src-tyrosine kinase (Nakano et al., 1987; Fallon, 1990). Its most potent inhibitory effect is exerted against PKC with a $2.7 \mathrm{nM}$ inhibition constant (Tamaoki et al., 1986). Recent investigations have indicated that STSP can reversibly arrest normal, nontransformed cells in $\mathrm{G} 1$ of the cell cycle when present at low concentration, i.e., $1 \mathrm{ng} / \mathrm{mL}$, whereas much higher concentrations $(75-100 \mathrm{ng} / \mathrm{mL})$ are required to arrest transformed cells in both G1 and G2 (Crissman et al., 1991). Such findings suggest that STSP might be used as an adjuvant to spare normal cells during some types of cancer therapy that preferentially target cycling cells.

Given this possibility, we set out to examine the usefulness of STSP in bringing about a state of G1 arrest in vivo using rats and mice as the experimental models. The first study series (I) focused on examining the effects of STSP on the distribution of DNA in bone marrow cells harvested from rat femurs 24-72 hrs after intravenous (i.v.) bolus injections of STSP followed by continuous i.v. infusion of the drug. The i.v. route for administering STSP in these studies was based on the assumption that a continuous concentration of STSP, i.e., $1 \mathrm{ng} / \mathrm{mL}$, at tissue sites of interest would likely be required over an extended period to bring about a state of $G 1$ arrest in normal cells. In a second study series (II), the duration of STSP treatment ranged from 48-120 hrs, and, in addition to bone marrow cells, alveolar macrophages, thymocytes, and splenocytes were examined for evidence of STSP-induced G1 arrest. The DNA distributions in cells studied during these two series of studies were analyzed by flow cytometry.

The goal in these investigations was to attempt to create a condition of STSP-induced G1 arrest, as previously indicated, in the absence of untoward responses that potentially may occur due to the broad protein kinase inhibitory activity of STSP. An example of an untoward response to STSP is hypotension (Secrest et al., 1991), which is likely attributable to the ability of this drug to induce relaxation of vascular smooth muscle cells via the inhibition of kinases that are involved in regulating smooth muscle tone, e.g., Buchholz et al., 1991. STSP dose regimens used in the I and II study series were based on a pharmacokinetic model (to be described), but because inherent variables such as the apparent volume of distribution of STSP administered via the i.v. route and the elimination rate(s) of STSP from the blood compartment and other body sites were unknown, these experiments were performed by trial and analysis using arbitrarily imposed values for these variables. 
In a third study series (III), the effects of STSP on the proliferation of rat femur bone marrow (BM) cells and alveolar macrophages (AM) were examined in vitro. Data obtained from the in vivo studies I and II indicated no response to the STSP treatment in the rat target cell populations examined. Therefore, the in vitro study was carried out to confirm that STSP can inhibit the proliferation of rat cells. The results from this study: 1) verified that the target cells are indeed inhibited from proliferating in the presence of STSP at very low concentrations (1-10 $\mathrm{ng} / \mathrm{mL}$ ), 2) established the possibility of producing a state of $\mathrm{G1}$ arrest and anti-proliferation of the target cells in vivo if the dosimetry for the drug to target cells could be appropriately regulated, and 3) suggested that the failure to bring about a demonstrable condition of G1 arrest in vivo in our previous studies may have been primarily due to the delivery of inappropriate concentrations of STSP to target cell compartments in the body. The latter conclusion was not unexpected, given the likely complex behavior of STSP in the body. STSP is a highly hydrophobic compound that is quickly bound to receptors on capillary endothelial cell membranes (Herbert et al., 1991), and, as we found in sudies subsequently performed after the series 1 and 2 studies, its dissemination in and removal from a seemingly simple compartment such as the blood consists of numerous components (Umbarger et al., 1993). Such factors lend to the complexity of achieving efficacious but untoward concentrations of STSP in body compartments of interest.

The fourth study series (IV) targeted the duodenums of the gastro-intestinal (GI) tracts of mice. This portion of the GI tract consists of an inherently high proliferating cell population where the effects of STSP may be detected. The routes of STSP delivery in this study component consisted of daily intraperitoneal (i.p.) injections or STSP incorporated into food, which was available for consumption ad libitum. Bromodeoxyuridine was administered to the animals to label proliferating cells.

In the fifth study series (V), newly obtained pharmacokinetic data for STSP administered intravascularly was incorporated into the pharmacokinetic model employed in the first set experiments (I and II) in order to further refine the dosimetry of STSP, and an initial set of experiments was performed with rats using the new dosing strategy. In this study, DNA distributions in alveolar macrophages, thymocytes, and bone marrow cells were examined by flow cytometry as in the I and II study series.

\section{Materials and Methods}

\section{Study Series I and II}

Animals: Adult, male Fisher 344 rats (specific pathogen-free, virus-free Harlan Sprague Dawley, Inc., Indianapolis, IN) were housed in quarantine for two weeks before use. They were 
kept on a 12 hour light-dark cycle with food and water ad libitum before and during the treatment period.

Staurosporine (Kamiya, Thousand Oaks, CA): For Series I and III investigations, STSP was solubilized in dimethyl sulfoxide (DMSO, J. T. Baker, Phillipsburg, NJ.) to yield a final stock concentration of $1 \mu \mathrm{g} / \mu \mathrm{L}$. For Study Series II investigations, STSP was solubilized in 1:1 polyethylene glycol-400 (PEG, J.T. Baker) and $10 \%$ dextrose $/ \mathrm{H}_{2} \mathrm{O}$ solution to yield the same concentration as above. For constant STSP infusions, fresh sterile STSP solutions were prepared daily and kept in the dark. STSP was diluted to desired concentrations in $10 \%$ dextrose $/ \mathrm{H}_{2} \mathrm{O}$ from stock solutions.

Intravascular Catheterizations and Infusions: The right jugular vein was catheterized using aseptic techniques as described by Hayes and Will (1978). Briefly, each rat was anesthetized using enflurane in air $(5 \% \mathrm{~V} / \mathrm{V}, 2 \mathrm{~L} / \mathrm{min})$. A small central dorsal portion of the neck was shaved along with the ventral portion overlying the right jugular vein. Betadine was applied to the shaved ventral surface. A small incision was made just above the jugular vein, and the underlying tissue was separated by blunt dissection. The jugular vein was isolated and ligatures were place at the cranial and caudal ends. A hemostat was placed cranially on the jugular, and a small incision was made on the vein. A sterile catheter (PE50, o.d.: 0.038 ", i.d.: 0.023 ", Tygon) fitted with a $3 \mathrm{~cm}$ silastic tubing tip (o.d.: 0.037". i.d.: 0.020", Dow Corning, Midland, MI) was inserted and advanced to position the tip just above the right atrium. The remaining catheter tubing was routed subcutaneously to the small incision previously made on the central dorsal surface. The long catheter was passed into a flexible steel tube and attached to the constant infusion pump (Manostat, peristaltic cassette. The tube was pre-filled with $10 \%$ heparinized saline (Elkins-Sinn, Cherry Hill, NJ) to prevent clotting at the tip. The tissue and the skin were closed with 3.0 and 4.0 silk sutures, respectively, and the animals were placed in a harness to secure the catheter (Stavert et al., 1987). In the first study series (I), the animals received an i.v. bolus injection of STSP, followed by constant i.v. infusion of STSP, which was regulated by the peristaltic pump. For a bolus injection, a hemostat was placed near the open end of the catheter to prevent backflow. A 23 ga. needle attached to a $1 \mathrm{~mL}$ syringe filled with STSP was attached to the open end. Any resulting air bubbles were eliminated. The hemostat was released and the full bolus volume $(100 \mu \mathrm{L})$ of STSP was delivered over a 30 second injection period. A chase solution of $0.5 \mathrm{~mL} 10 \%$ dextrose $/ \mathrm{H}_{2} \mathrm{O}$ was injected over 45 seconds to clear the catheter dead space $(0.2 \mathrm{~mL})$.

For the constant i.v. infusions, the peristaltic pump was calibrated to deliver at a rate of $0.5 \mathrm{~mL} / \mathrm{hr}$. A $30 \mathrm{~mL}$ syringe, wrapped in aluminum foil to shield light, served as the STSP 
reservoir. Tubing (Manosil, silicon rubber, o.d.: 0.03125 ", i.d.: 0.015 ") from the $30 \mathrm{~mL}$ syringe was routed through the pump and attached to a connector. The open end of the catheter was fitted to the other end of the connector. Twenty-three ga. needles were used to fit the tubing to the connector and the $30 \mathrm{~mL}$ syringe. Initially, the pump was set on maximum flow rate to fill the tubing and connector and remove all air bubbles. The pump was then reset to deliver at 0.5 $\mathrm{mL} / \mathrm{hr}$ or $1 \mathrm{~mL} / \mathrm{hr}$, and control volumes were collected in $1 \mathrm{~mL}$ syringes to calibrate the pump. All subsequent i.v. infusions were delivered at either 0.5 or $1.0 \mathrm{~mL} / \mathrm{hr}$.

Dosimetry: Pharmacokinetic information about STSP has not been reported in the literature; accordingly, there are no previous publications concerning its volume of distribution, its biodisposition, or its rate(s) of elimination from the body or its subcompartments. The only information concerning the pharmacokinetics of STSP have been obtained from HPLC analysis performed by Gurley and co-workers at LANL. Analysis of blood samples from intravenously injected STSP rats have produced evidence of a 2:1 partitioning between the erythrocytes and the plasma compartments (Umbarger et al., 1993). Such findings suggest that STSP administered in vivo may be less than uniformly delivered and sequestered at tissue sites of interest.

Given the lack of information about the pharmacokinetics of STSP in the body, a general mathematical-pharmacokinetic model was used as a first line approach for developing STSP dose regimens. As a starting condition, it was initially assumed that STSP administered via the intravascular route would have a volume of distribution limited to the plasma compartment, and that the rate of elimination of STSP from this compartment follows a simple first order pattern. For the sake of dosimetric considerations, widely ranging, potential half times for the elimination of STSP were also assumed. As a specific example, the blood volume of an adult rat is $\sim 10 \mathrm{~mL}$, and the hematocrit is $\sim 45 \%$. The plasma compartment, accordingly makes up $\sim 5.5 \mathrm{~mL}$ (55\% of total blood volume) of the whole blood compartment. Thus, the apparent volume of distribution in the earliest studies was assumed to be only $\sim 5.5 \mathrm{~mL}$. The rate of elimination was assumed, as previously indicated, to be a first order process, which can be satisfactorily described by a single rate constant. The equation that describes the model is as follows:

$$
S_{(t)}=S_{(0)} \cdot e^{-K o u t(t)}+M_{(\text {in })} / K_{(\text {out })} \cdot\left(1-e^{-K o u t}(t)\right)
$$

$S_{(t)}=$ concentration of STSP at any given time $t$ following the administration of STSP.

$\mathrm{S}_{(0)}=$ concentration of STSP immediately following a bolus injection.

Kout=rate of STSP elimination.

$\mathrm{M}_{\text {(in) }}$ STSP infusion rate required to maintain constant concentration. 
The above model is typical for conditions that involve an immediately delivered and constantly maintained concentration of a drug in a body compartment. For example, in order to theoretically establish an initial concentration of $10 \mathrm{ng} \mathrm{STSP} / \mathrm{mL}$ in the plasma compartment, a $55 \mathrm{ng}$ IV bolus injection was made at time 0 , assuming a $5.5 \mathrm{~mL}$ volume of distribution. Then, by imposing a theoretical elimination half time for STSP, the amount of STSP theoretically eliminated over a given interval can be precisely calculated. To sustain the initial concentration of $10 \mathrm{ng} / \mathrm{mL}$ in the assumed distribution volume, the rate at which STSP is eliminated must be quantitatively balanced and replenished via continuous infusion $\left[\mathrm{M}_{(\mathrm{in})}\right]$. Some experimental model imposed half times and their $\mathrm{K}_{\text {(out) }}$ values are given in Table 1.

Table 1: STSP Elimination Rate Values Imposed on the Pharmacokinetic Model

\begin{tabular}{cl}
\hline Imposed half times $\left(\mathrm{t}_{1 / 2}-\mathrm{hr}\right)$ & $\mathrm{K}_{(\text {out })}\left[\mathrm{K}_{\text {(out) }}=0.693 / \mathrm{t}_{1 / 2}\right]$ \\
4 & $0.1733 / \mathrm{hr}$ \\
8 & $0.0866 / \mathrm{hr}$ \\
12 & $0.0578 / \mathrm{hr}$ \\
24 & $0.0289 / \mathrm{hr}$ \\
\hline
\end{tabular}

The same mathematical model was employed in calculating various bolus and i.v. infusion rates corresponding to other assumed volumes of distribution and elimination half times. Overall, the apparent volumes of distribution examined ranged from $5.5 \mathrm{~mL}$ to $270 \mathrm{~mL}$, i.e., $\sim$ total body water in a $300 \mathrm{~g}$ rat.

Animal Sacrifices and Preparation of Study Cell Populations: The rats were anesthetized with intraperitoneal i.p. injections of $50 \mathrm{mg}$ Nembutal (Abbott, Chicago, IL), and they were exsanguinated prior to total apnea by carotid artery transection.

Alveolar macrophages (AM) were collected by bronchoalveolar lavage (Lehnert $e t$ al., 1989). The trachea was isolated and cannulated with a blunt 18 ga. needle secured by ligature, the trachea and lungs were removed en bloc, and the heart, thymus, esophagus and other connective tissue were removed. A $10 \mathrm{~mL}$ syringe filled with $8 \mathrm{~mL}$ cold PBS was attached to the cannula, and the lung was lavaged 6 times with separate aliquots of the PBS as the lungs were gently massaged. The lavage fluid retrieved from each wash cycle was pooled in a tube maintained on ice. Total recovered cell numbers and cell viability analyses using trypan blue exclusion were performed with a hemocytometer. The cells were centrifuged at $300 \mathrm{~g}$ for 10 min. The supernatant was aspirated, and the $A M$ were resuspended to a concentration of $106 / \mathrm{mL}$ 
in 3:1 95\% ethanol:EDTA and stored at $-20^{\circ} \mathrm{C}$ for subsequent DNA quantification labeling and flow cytometric analysis.

The bone marrow (BM) cells were obtained from the same rat used to collect the AM. The left femur was surgically removed and the soft tissue was dissected from the bone. Both proximal and distal ends of the femur were removed to expose the marrow cavity. The marrow cavity was flushed using an 18 ga. needle attached to a $30 \mathrm{~mL}$ syringe filled with $30 \mathrm{~mL}$ of $0.5 \%$ $\mathrm{BSA} / \mathrm{CO}_{2}$-independent media (Gibco). The marrow was collected in a tube maintained on ice and aspirated several times through a trochar to disaggregate cell clumps. The BM cells were centrifuged at $300 \mathrm{~g}$ for $10 \mathrm{~min}$. The supernatant was aspirated, and the BM cells were resuspended in $15 \mathrm{~mL}$ red blood cell (RBC) lysis buffer (tris-buffered ammonium chloride) in a $37^{\circ} \mathrm{C}$ water bath for $15 \mathrm{~min}$. The cells were then filtered through a nylon filter $(0.2 \mu \mathrm{m})$ and recentrifuged. They were then resuspended in $0.5 \% \mathrm{BSA} / \mathrm{CO}_{2}$-independent media, and a cell count was performed using a hemocytometer. The BM cells were fixed at a concentration of $10^{6}$ cells/mL in 3:1 $95 \%$ ethanol:EDTA and stored at $-20^{\circ} \mathrm{C}$ for subsequent DNA quantification labeling and flow cytometric analysis.

The thymus was surgically removed. A small portion of the thymus was shredded using forceps in a petri dish. The thymocytes were collected in a tube maintained on ice and, using an 18 ga. needle attached to a $30 \mathrm{~mL}$ syringe filled with $30 \mathrm{~mL}$ of $0.5 \% \mathrm{BSA} / \mathrm{CO}_{2}$-independent media (Gibco), aspirated several times through a trochlar to disaggregate cell clumps. The thymocytes were centrifuged at $300 \mathrm{~g}$ for $10 \mathrm{~min}$. The supernatant was aspirated, and the cells were resuspended in $0.5 \% \mathrm{BSA} / \mathrm{CO}_{2}$-independent media. The cells were then filtered through a nylon filter $(0.2 \mu \mathrm{m})$. A cell count was performed using a hemocytometer. The thymocytes were fixed at a concentration of $10^{6}$ cells $/ \mathrm{mL}$ in $3: 195 \%$ ethanol:EDTA and stored at $-20^{\circ} \mathrm{C}$ for subsequent DNA quantification labeling and flow cytometric analysis.

The spleen was surgically removed. A small portion of the spleen was shredded using forceps in a petri dish. The splenocytes were collected in a tube maintained on ice and, using an $18 \mathrm{ga}$. needle attached to a $30 \mathrm{~mL}$ syringe filled with $30 \mathrm{~mL}$ of $0.5 \% \mathrm{BSA} / \mathrm{CO}_{2}$-independent media (Gibco), aspirated several times through a trochlar to disaggregate cell clumps. The splenocytes were centrifuged at $300 \mathrm{~g}$ for $10 \mathrm{~min}$. The supernatant was aspirated, and the cells were resuspended in $0.5 \% \mathrm{BSA} / \mathrm{CO}_{2}$-independent media. The cells were then filtered through a nylon filter $(0.2 \mu \mathrm{m})$. A cell count was performed using a hemocytometer. The splenocytes were fixed at a concentration of $10^{6}$ cells $/ \mathrm{mL}$ in $3: 195 \%$ ethanol:EDTA and stored at $-20^{\circ} \mathrm{C}$ for subsequent DNA quantification labeling and flow cytometric analysis

Flow Cytometric Analysis of Cellular DNA: The FMF II flow cytometer (Holm and Cram, 1973) operates using a 5 watt maximum argon ion laser (Coherent innova 90) at a 
wavelength of $457 \mathrm{~nm}$. An on-line Digital computer recorded the data and histograms. Chinese hamster ovary $(\mathrm{CHO})$ cells $\left(10^{6} / \mathrm{mL}\right)$, treated with mithramycin, were used as a standard to calibrate the flow cytometer. Sample cells were identically stained as the $\mathrm{CHO}$ cells. Approximately $2 \times 10^{6}$ cells of the previously fixed cells were vortexed and centrifuged (10 min at $1200 \mathrm{rpm}$ ) and the supernatants were aspirated. The cells were resuspended in mithramycin $(50 \mu \mathrm{g} / \mathrm{mL})$ at $10^{6} \mathrm{cells} / \mathrm{mL}$ and vortexed. The cells were shielded from light and stored overnight in the refrigerator.

Stock mithramycin solution was made with $2.5 \mathrm{~g}$ mithramycin in $50 \mathrm{~mL}$ stock saline solution containing $10 \mathrm{mM}$ tris and $20 \mathrm{mM} \mathrm{MgCl}_{2}$. The stock solution was shielded from light with foil and stored at $-4^{\circ} \mathrm{C}$. An acceptable coefficient of variable (CV-distribution of cells around a single channel) was determined to be below 3.5 for the samples. The data were then transferred to the VAX system at LANL for final data analysis using the Cellcycle (FM Fit) program (Jett, 1991).

The cellular DNA is stained stoichiometrically, so that the amount of incorporated stain is proportional to the amount of DNA. Theoretically, all cells in G1 should have a single DNA content (same fluorescence) recorded as a very sharp spike in a single channel. Then it would follow that all cells in G2 should have exactly twice the G1 DNA content represented by a single channel peak, and cells in $S$ phase should have an intermediate DNA content. However, because of variable DNA dye binding and instrument error, the G1 and G2 peaks are represented as a normally distributed Gaussian curve measured in terms of coefficient of variables. The same factors effect the S-phase distribution, in effect widening the S-phase to overlap with the G1 and G2 peaks.

Both the Cellcycle and Multicycle (Phoenix Flow Systems, San Diego, CA) programs describe the DNA histogram with a series of overlapping Gaussian curves to estimate the G1 and G2 peaks. A polynomial curve fit of the central S-phase region using the Dean and Jett method or the broadened polynomial method calculates the S\% (Dean and Jett, 1974). The Cellcycle program uses a second order polynomial fit of the S-phase along with Gaussian curve distributions of the $\mathrm{G} 1$ and $\mathrm{G} 2$ peaks. This method has been accepted for cells with a normal cell cycle, which may have cells in transition between phases (i.e. G1-S or S-G2+M). However, for cells with a disturbed cell cycle (e.g., G1 arrest), it may overestimate the S-phase when the broadening at the bases of the Gaussian curves describing the G1 and G2 peaks overlaps with the multiple Gaussians describing the S-phase. In effect, the second order polynomial program incorporates additional cells into the S-phase total from the G1-early S and late S-G2 transition points.

All Study Series II data were analyzed using both programs. The Multicycle program, in addition to the second order polynomial fit, using the Gaussian curve fit of G1 and G2 peaks, 
also offers first (slope) and zero (linear) order S-phase fits. This allows for less overlap between the G1 and G2 peaks and the S-phase, and it gives a more conservative estimate of the S-phase content. The different S-phase polynomial also helps to reduce background signals due to debris. Aggregates and fractured cells may contribute to the debris signal. The results obtained with this program did not importantly differ significantly from the Cellcycle program results.

\section{Study Series III}

Effects of STSP on Alveolar Macrophage (AM) Proliferation In Vitro: We attempted to achieve a state of STSP-induced inhibition of proliferation of rat cells as an indirect index of G1 arrest using lavaged rat AM cultured in the presence of STSP. AM proliferation assays were performed using 6-well, $35 \mathrm{~mm}$ dia. culture plates fitted with porous $(0.45 \mu \mathrm{m}$ pores), collagencoated membrane inserts (Transwells ${ }^{\circledR}$, Costar Corp., Cambridge, MA). Control cells suspended in $10 \%$ FBS- $\alpha$ Minimum Essential Medium ( $\alpha$ MEM) containing $0.5 \mathrm{ng} / \mathrm{mL}$ recombinant murine Granulocyte/Macrophage Colony-Stimulating Factor (rmGM-CSF, Genzyme, Cambridge, MA) as a growth factor for the AM were added atop the inserts, and the bottom wells were filled with the corresponding culture medium. The experimental media contained $1 \mathrm{ng} / \mathrm{mL}$ STSP in addition to the control media. $1 \times 10^{4} \mathrm{AM}$ were seeded per well for the proliferation studies. After being cultured 7 days at $37^{\circ} \mathrm{C}$ in $5 \% \mathrm{CO}_{2}$-air, the cells were harvested from the inserts. The plates were placed on ice for $30 \mathrm{~min}$, and afterwards the cells on the inserts were jetted with the media from the bottom well to collect weakly the AM. Thereafter, the inserts were further washed 3 times with $0.5 \% \mathrm{BSA} / \mathrm{CO}_{2}$-independent media to harvest remaining cells. All wash fluids from a given well were collectively pooled in a polypropylene tube that was maintained on ice. The plates were routinely checked under an inverted microscope after the cell removal procedure to verify that all cells were harvested from the inserts. The recovered cells were counted with a hemocytometer, and total number of cells present per well after 7 days in culture were determined from these counts.

Effects of STSP on Bone Marrow Cell Proliferation In Vitro: Control media for the BM cell study consisted of 40\% L929 cell-conditioned medium (as a source of Macrophage Colony-Stimulating Factor) and 60\% 10\% FBS- $\alpha$ MEM. L929 cell supernatants induce BM cell proliferation and differentiation into macrophages (Boltz-Nitulescu et al., 1987). STSP was added to cultures at concentrations of 1 or $10 \mathrm{ng} / \mathrm{mL}$; control wells received the carrier vehicle (DMSO) at corresponding volumes ( 1 or $10 \mu \mathrm{L} / \mathrm{mL}$ ). The BM cells were seeded at $10^{4}$ cells/well atop the inserts of Costar Transwell plates, and cultured for 3 weeks. Cultures were provided with fresh media every 7 days. The BM cells were harvested and counted in the same manner as previously described for the AM. 


\section{Study Series IV}

Animals: Six to eight week old, male $\mathrm{C} 3 \mathrm{H} / \mathrm{HEJ}$ mice (specific pathogen-free, Jackson Laboratories, Bar Harbor, ME) were housed in quarantine for one week prior to use. They were kept on a $12 \mathrm{hr}$ light-dark cycle with food and water being provided ad libitum before and during the treatment period.

Staurosporine and 5-Bromo-2'-Deoxyuridine (BrdU) Stock Solutions: STSP was solubilized in PEG-400 (J.T. Baker) and dextrose/ $\mathrm{H}_{2} \mathrm{O}$ to a stock concentration of $0.25 \mu \mathrm{g} / \mu \mathrm{L}$ or $1 \mu \mathrm{g} / \mu \mathrm{L}$. BrdU (Sigma, St. Louis, MO) was solubilized at $50 \mathrm{mg} / \mathrm{mL}$ in sterile PBS with heat $\left(37^{\circ} \mathrm{C}\right)$ and stirring.

Feeding Schedule: Laboratory chow pellets were ground to a powder using an industrial blender. Enough chow powder ( $20 \mathrm{~g} /$ day/rat; $5 \mathrm{~g} /$ day/mouse) for a week's worth of feeding were weighed and mixed with STSP solution ( $1 \mu \mathrm{g} / \mu \mathrm{L}$ in DMSO), at $10 \mu \mathrm{g} / \mathrm{g}$-food, along with $30 \mathrm{~mL}$ dextrose $/ \mathrm{H}_{2} \mathrm{O}$ and gelatin or $100 \%$ ethanol. The dextrose $/ \mathrm{H}_{2} \mathrm{O}$ and gelatin or $100 \%$ ethanol solution was slowly incorporated into the mixture with constant folding to reconstitute the powder into pellets. Corresponding volumes of dextrose/ $\mathrm{H}_{2} \mathrm{O}$ were added to control food pellets. The reformed food pellets were dehydrated overnight at room temperature. The animals were fed small portions daily. Control and study group animals were deprived of food for $12 \mathrm{hrs}$ prior to the first feeding. Water was provided ad libitum.

Rats: The control $(n=2)$ and study $(n=6)$ groups of rats received approximately $20 \mathrm{~g}$ of food per day ( $200 \mu \mathrm{g}$ total STSP/day/rat) for 4 days.

Mice: The control $(\mathrm{n}=2)$ and study $(\mathrm{n}=6)$ groups of mice received approximately $5 \mathrm{~g}$ of food per day ( $50 \mu \mathrm{g}$ total STSP/day/mouse) for 5 or 10 days.

Injection Experiments/Schedules: A control group $(n=8)$ of rats received $250 \mu \mathrm{L}$ daily intraperitoneal (i.p.) injections of PBS. A STSP-treatment group of rats received a daily $100 \mu \mathrm{g}$ $(100 \mu \mathrm{L})(\mathrm{n}=8)$ or $250 \mu \mathrm{g}(250 \mu \mathrm{L})(\mathrm{n}=2)$ i.p. injection of STSP $(1 \mu \mathrm{g} / \mu \mathrm{L}$ in PEG and dextrose $/ \mathrm{H}_{2} \mathrm{O}$ ). These treatments were given for 3, 4 and 7 days. From each STSP-treated group, two animals were sacrificed on day 3 and 4 animals were sacrificed on days 4 and 7 . Two animals were sacrificed on days 3,4 and 7 from the control group.

A control group of mice $(n=10)$ received daily $100 \mu \mathrm{L}$ i.p. injections of a 1:3 solution of PEG:dextrose $/ \mathrm{H}_{2} \mathrm{O}$. A STSP-treatment group of mice received a daily dose of either $25 \mu \mathrm{g}$ 
$(\mathrm{n}=20)$ or $100 \mu \mathrm{g}(\mathrm{n}=4)$ of STSP (PEG and dextrose/ $\mathrm{H}_{2} \mathrm{O}$ ) in a $100 \mu \mathrm{L}$ total volume i.p. injection. The treatment schedule was for $4,7,10$ and 12 days. Four animals receiving $25 \mu \mathrm{g} / \mathrm{day}$ were sacrificed on days 4,7 and 10 days. Eight animals receiving $25 \mu \mathrm{g} /$ day were sacrificed on day 12. For pulse labeling with BrdU, rats received a $100 \mathrm{mg} / \mathrm{kg}$ dose $(1 \mathrm{~mL})$ by i.p. injection $4 \mathrm{hrs}$ prior to sacrifice. Mice received a $25 \mathrm{mg}(\sim 1 \mathrm{~mL})$ total BrdU dose by i.p. injection 4 hrs prior to sacrifice.

Tissue Harvesting: Animals were sacrificed at the various post-treatment times by cervical dislocation (mice) or lethal i.p. injections with pentobarbital sodium (rats). An $\sim 2-3 \mathrm{~cm}$ section of the duodenum with an adjoining section of pancreas were surgically removed and the duodenum was gently flushed with PBS several times to clear its contents. The sections were fixed in 10\% formalin-phosphate buffered saline and shipped to a commercial laboratory (Veritas Laboratories, Raleigh-Durham, NC) for immunohistochemical development of BrdU-labeled cells.

\section{Study Series $V$}

Our findings from HPLC analysis of STSP in the plasma and erythrocyte compartments (Gurley et al., 1994) following bolus i.v. injection of STSP provided a more analytical basis for STSP dosing in rats.

For the data shown in Figure 1, a $250 \mu \mathrm{g}$ bolus of STSP $(250 \mu \mathrm{L}$ vol., $1 \mu \mathrm{g} / \mu \mathrm{L}$ in PEG) was directly injected, using a $500 \mu \mathrm{L}$ Hamilton syringe, into the right jugular vein at time $=0$; this injection was followed by a $200 \mu \mathrm{L}$ chase solution of PBS. Blood samples were taken by cardiac puncture from diferent rats at different times ranging from 5 to $240 \mathrm{~min}$ after injection. A blood sample was also taken from a rat injected with the same solution containing no STSP for use as a baseline control. The whole blood was centrifuged at $300 \mathrm{~g}$ for $7 \mathrm{~min}$ to separate the plasma and erythrocytes. The two blood subcompartments were analyzed by a new analytical HPLC technique designed to detect and quantitate STSP in blood samples (Gurley et al., 1994). Independent data points were plotted with $\mathrm{ng} \mathrm{STSP} / \mathrm{mL}$ detected versus time, and a least squares fit line with a linear regression $\left(\mathrm{r}^{2}\right)$ value of 0.81 was generated for the plasma compartment. A least squares 

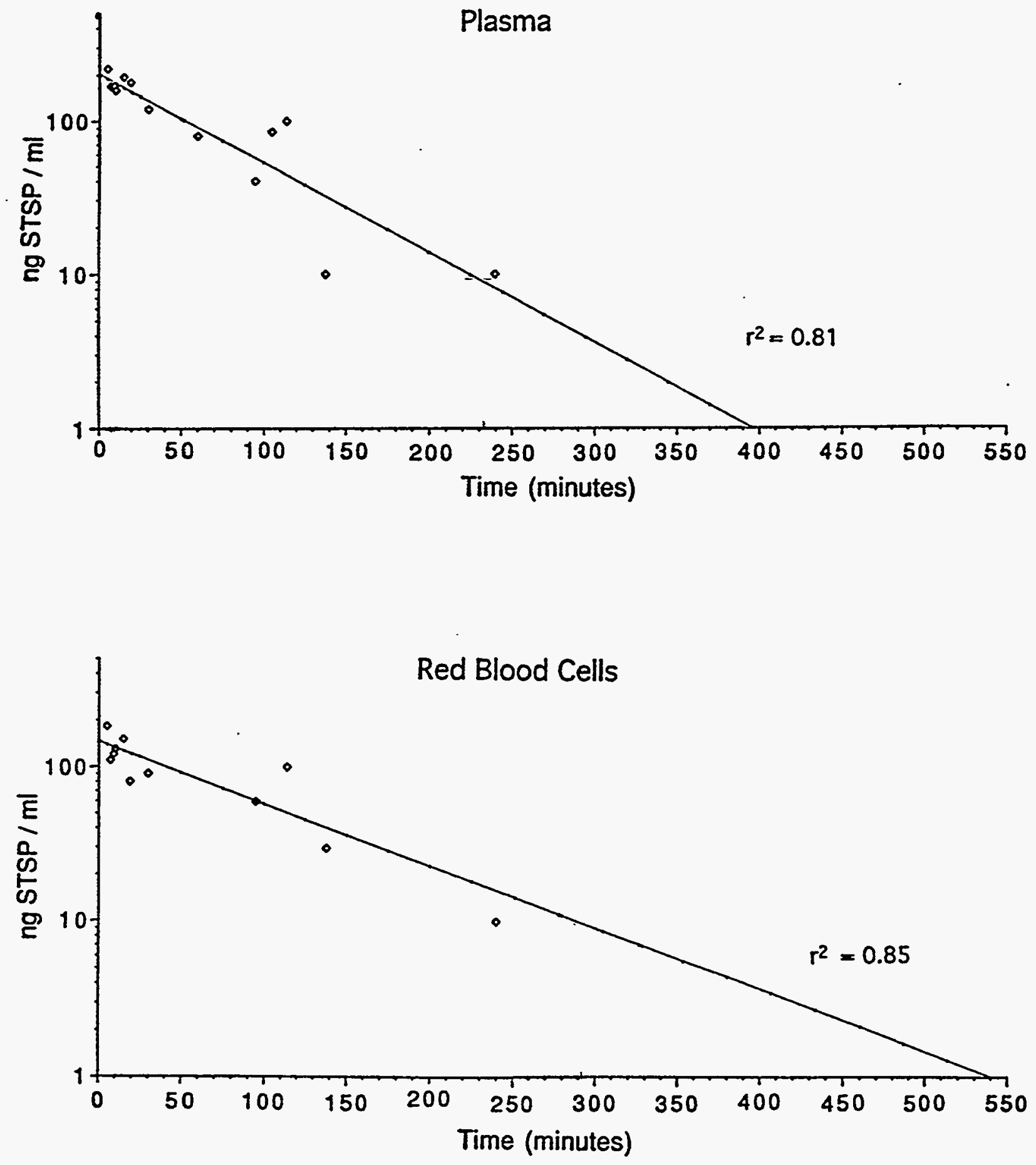

Figure 1: Concentrations of STSP in plasma and erythrocytes at various times following the bolus injection of $250 \mu \mathrm{g}$ STSP. The half-times for elimination of STSP from the plasma and erythrocyte compartments were estimated to be 52 and $75 \mathrm{~min}$, respectively. 
fit line with an $\mathrm{r}^{2}$ of 0.85 was also fitted for the erythrocyte compartment. From the $\mathrm{t}=0$ intercept values, an average total of $3.5 \mu \mathrm{g}$ STSP was estimated to be present in $10 \mathrm{~mL}$ of whole blood (plasma + erythrocyte content) immediately after the bolus injection; this value translates into an apparent volume of distribution of $\sim 71 \mathrm{~mL}$ for the initially injected $250 \mu \mathrm{g}$ bolus of STSP. The half times for elimination of STSP from the erythrocyte and plasma compartments were estimated to be 75 and $52 \mathrm{~min}$, respectively. Because of the similarity in these values, they were averaged for an estimation of the rate of removal of STSP from the blood $\left(\mathrm{K}_{\mathrm{out}}=0.693 / 63\right.$ $\min =0.011$ ), and the $K_{\text {out }}$ value was incorporation into the pharmacokinetic model to determine the constant infusion rate.

To achieve an initial $10 \mathrm{ng} / \mathrm{mL}$ STSP concentration in the $71 \mathrm{~mL}$ volume of distribution, a bolus injection of $7.1 \mu \mathrm{g} \mathrm{STSP}$ was calculated. For sustaining a constant blood concentration of $10 \mathrm{ng} / \mathrm{mL}$, a constant infusion rate $\left(\mathrm{M}_{\mathrm{in}}\right)$ was calculated to be $0.109 \mathrm{ng} \mathrm{STSP} / \mathrm{min}$.

The bolus/i.v. injection data from previous studies (I and II) were reanalyzed in the context of the new pharmacokinetic model, i.e., new elimination half-life and different volumes of distribution, to estimate STSP levels that may have been achieved in the blood during those studies.

\section{Results}

\section{Study Series I}

Indwelling i.v. catheters were surgically implanted to deliver continuous infusions of STSP following a bolus injection of the drug. Different amounts of STSP for bolus injections and continuous infusion rates were calculated based on the mathematical-pharmacokinetic model and theoretical considerations described earlier. The DNA distributions of bone marrow cells (BM) were quantitated using flow cytometric techniques. The data summarized in Table 2 were analyzed using the Cellcycle program.

No evidence was obtained to suggest that any of the STSP treatment strategies importantly altered the DNA distributions in BM cells from values obtained with cells harvested from untreated control animals. Death occurred in four of nine animals treated at $200 \mu \mathrm{g}$ bolus injections followed by $17 \mathrm{ng} / \mathrm{mL}$ ( $757 \mu \mathrm{g}$ total) i.v. infusion for less than $24 \mathrm{hrs}$. Similarly, three of four animals treated at $175 \mu \mathrm{g}$ bolus injection followed by $10 \mathrm{ng} / \mathrm{mL}$ (696 $\mu \mathrm{g}$ total) i.v. infusion for 48 hours died (Table 2). Presumably, the death of these animals was due to STSPinduced hypotension. 


\section{Study Series II}

In this study series, STSP was administered by continuous i.v. infusion without bolus injections. In addition to the distributions of DNA in BM cells, AM, thymocytes and splenocytes

\section{Table 2. Study Series I Results of Bone Marrow Cell DNA Distribution Analyses after Various STSP Treatment Regimens. (G1, S and G2+M\% \pm SEM).}

DNA Distribution in Rat Femur Bone Marrow Cells

\begin{tabular}{|c|c|c|c|c|c|c|c|c|}
\hline $\begin{array}{l}\text { Bolus } \\
\text { injection }\end{array}$ & $\begin{array}{c}\text { STSP } \\
\text { infusion rate } \\
\text { mass } / \mathrm{hr}\end{array}$ & $\begin{array}{l}\text { Avg total } \\
\text { STSP received }\end{array}$ & $\begin{array}{l}\text { Assumed } \\
\text { clearance half } \\
\text { time }\end{array}$ & $\begin{array}{l}\text { Treatment } \\
\text { time (hr) }\end{array}$ & $\mathbf{n}$ & $\% \mathrm{G} 1$ & $\% \mathrm{~S}$ & $\% \mathrm{G} 2+\mathrm{M}$ \\
\hline control & - & - & - & - & 6 & $79.5 \pm 0.44$ & $14.7 \pm 0.61$ & $5.8 \pm 0.58$ \\
\hline $55 \mathrm{ng}$ & $19.03 \mathrm{ng}$ & $340.5 \mathrm{ng}$ & $2 \mathrm{hr}$ & 24 & 4 & $76.4 \pm 0.95$ & $19.4 \pm 0.77$ & $4.3 \pm 0.81$ \\
\hline $55 \mathrm{ng}$ & $19.03 \mathrm{ng}$ & $536.5 \mathrm{ng}$ & $2 \mathrm{hr}$ & 48 & 2 & $80.2 \pm 0.50$ & $15.0 \pm 3.40$ & $4.8 \pm 2.90$ \\
\hline $55 \mathrm{ng}$ & $9.52 \mathrm{ng}$ & $508.2 \mathrm{ng}$ & $8 \mathrm{hr}$ & 48 & 2 & $78.3 \pm 3.20$ & $15.0 \pm 2.25$ & $6.8 \pm 1.10$ \\
\hline $1.9 \mu \mathrm{g}$ & $328.8 \mathrm{ng}$ & $10.9 \mu \mathrm{g}$ & $4 \mathrm{hr}$ & 24 & 3 & $80.8 \pm 1.85$ & $14.1 \pm 0.79$ & $5.1 \pm 2.03$ \\
\hline $1.9 \mu \mathrm{g}$ & $328.8 \mathrm{ng}$ & $20.2 \mu \mathrm{g}$ & $4 \mathrm{hr}$ & 48 & 2 & $83.0 \pm 6.20$ & $14.3 \pm 4.35$ & $2.8 \pm 1.75$ \\
\hline $1.9 \mu \mathrm{g}$ & $328.8 \mathrm{ng}$ & $26.7 \mu \mathrm{g}$ & $4 \mathrm{hr}$ & 72 & 2 & $84.2 \pm 0.95$ & $13.1 \pm 1.65$ & $2.8 \pm 0.67$ \\
\hline $19 \mu \mathrm{g}$ & $3.29 \mathrm{ng}$ & $104.4 \mu \mathrm{g}$ & $4 \mathrm{hr}$ & 24 & 2 & $73.1 \pm 5.50$ & $13.7 \pm 2.05$ & $13.3 \pm 7.54$ \\
\hline $19 \mu \mathrm{g}$ & $3.29 \mathrm{ng}$ & $142.7 \mu \mathrm{g}$ & $4 \mathrm{hr}$ & 48 & 1 & 80.5 & 12.8 & 6.7 \\
\hline $19 \mu \mathrm{g}$ & $3.29 \mathrm{ng}$ & $182.9 \mu \mathrm{g}$ & $4 \mathrm{hr}$ & 69 & 2 & $79.9 \pm 1.25$ & $18.1 \pm 0.50$ & $2.3 \pm 0.75$ \\
\hline $125 \mu \mathrm{g}$ & $7.22 \mu \mathrm{g}$ & $364.0 \mu \mathrm{g}$ & $12 \mathrm{hr}$ & 24 & 2 & $76.5 \pm 1.60$ & $14.8 \pm 2.80$ & $8.6 \pm 1.20$ \\
\hline $125 \mu \mathrm{g}$ & $7.22 \mu \mathrm{g}$ & $583.6 \mu \mathrm{g}$ & $12 \mathrm{hr}$ & 47 & 2 & $80.8 \pm 1.80$ & $14.1 \pm 1.70$ & $5.1 \pm 0.10$ \\
\hline $125 \mu \mathrm{g}$ & $7.22 \mu \mathrm{g}$ & $656.8 \mu \mathrm{g}$ & $12 \mathrm{hr}$ & 71 & 2 & $75.1 \pm 1.60$ & $18.2 \pm 0.80$ & $6.7 \pm 0.80$ \\
\hline $200 \mu \mathrm{g}$ & $17 \mu \mathrm{g}$ & $757.2 \mu \mathrm{g}$ & $8 \mathrm{hr}$ & 24 & 5 & $71.4 \pm 2.77$ & $21.2 \pm 1.98$ & $7.4 \pm 0.96$ \\
\hline $200 \mu \mathrm{g}$ & $17 \mu \mathrm{g}$ & died & & $<24$ & 4 & & & \\
\hline $175 \mu \mathrm{g}$ & $10.11 \mu \mathrm{g}$ & $447.0 \mu \mathrm{g}$ & $12 \mathrm{hr}$ & 24 & 2 & $66 \pm 1.85$ & $28.2 \pm 4.15$ & $5.9 \pm 2.3$ \\
\hline $175 \mu \mathrm{g}$ & $10.11 \mu \mathrm{g}$ & $728 \mu \mathrm{g}$ & $12 \mathrm{hr}$ & 48 & 1 & 63.8 & 8.5 & 7.7 \\
\hline $175 \mu \mathrm{g}$ & $10.11 \mu \mathrm{g}$ & $685.2 \mu \mathrm{g}$ & $12 \mathrm{hr}$ & 48 & 3 & died & & \\
\hline
\end{tabular}

were also analyzed for their DNA contents by flow cytometry. The DNA distribution data obtained in this study component were analyzed using the Cellcycle and Multicycle programs.

An initial experiment involved i.v. administration of $2 \mu \mathrm{g} / \mathrm{hr}$ STSP over 24,48 and 72 hours. Lavaged alveolar macrophage (AM) DNA distributions were analyzed by flow cytometry after staining with mithramycin. The data analyzed using the Cellcycle program appears in Table 3. The average control population S\% was $3.6 \%(n=3)$. The average S\% of the $24 \mathrm{hr}$ 
animals was $3.3 \%(n=2)$ and the average $48 \mathrm{hr}$ animals' S\% was $0.7 \%(n=2)$. Following the same protocol, we were unable to reproduce the $48 \mathrm{hr}$ results using the original samples at a later date; thus, it appears that the initial analyses giving low percentages of cells in $S$ were incorrect due to an unknown technical problem. Also, on follow-up studies, we were unable to produce similar results, even with increased concentrations of STSP over a prolonged period. AM from animals treated with $4 \mu \mathrm{g} / \mathrm{hr}$ (47 $\mu \mathrm{g}$ total) STSP over $71 \mathrm{hrs}$ had S\% of $\sim 2.0 \%$. AM from an animal treated with $2 \mu \mathrm{g} / \mathrm{hr}$ (62 $\mu \mathrm{g}$ total) STSP over $92 \mathrm{hrs}$ had an S\% of $2.4 \%$ (corresponding dose rate/hr and total calculated dose may not be equivalent due to an inconsistent pump delivery rate).

Table 3. Alveolar Macrophage DNA Distribution Analyzed Using Cellcycle and Multicycle Programs. (Average values given in \% \pm SEM.)

\begin{tabular}{|c|c|c|c|c|c|c|c|}
\hline & \multicolumn{7}{|c|}{$\mathbf{A M}$} \\
\hline & \multicolumn{5}{|c|}{ Cellcycle } & \multicolumn{2}{|c|}{$\begin{array}{l}\text { Multicycle } \\
\text { (all 1st order) }\end{array}$} \\
\hline & $\begin{array}{l}\text { Total dose } \\
\text { STSP }\end{array}$ & G 1 & $s$ & $\mathrm{G} 2+\mathrm{M}$ & G 1 & s & G2+M \\
\hline Control 1 & - & 93.01 & 3.36 & 3.64 & 92.6 & 2.6 & 4.8 \\
\hline Control 2 & . & 84.59 & 3.43 & 11.97 & 85.0 & 2.7 & 12.3 \\
\hline Control 3 & . & 85.58 & 3.93 & 10.49 & 85.2 & 3.5 & 11.3 \\
\hline avg & - & $87.73 \pm 2.66$ & $3.57 \pm 0.18$ & $8.7 \pm 2.25$ & $87.6 \pm 2.50$ & $2.9 \pm 0.29$ & $9.5 \pm 2.35$ \\
\hline $2 \mu \mathrm{g} / \mathrm{hr} 47$ hour & $26.5 \mu \mathrm{g}$ & 81.57 & 3.65 & 14.77 & 81.2 & 3.4 & 15.4 \\
\hline $2 \mu \mathrm{g} / \mathrm{hr} 47$ hour & $31.3 \mu \mathrm{g}$ & 89.99 & 3.03 & 6.98 & 89.9 & 2.6 & 7.5 \\
\hline avg & $28.9 \mu \mathrm{g}$ & $85.78 \pm 4.20$ & $3.34 \pm 0.31$ & $10.88 \pm 3.90$ & $85.6 \pm 3.55$ & $3.0 \pm 0.33$ & $11.5 \pm 3.95$ \\
\hline $2 \mu \mathrm{g} / \mathrm{hr} 71$ hour & $41.4 \mu \mathrm{g}$ & 87.2 & 1.8 & 11 & 87.1 & 1.9 & 11.0 \\
\hline $2 \mu \mathrm{g} / \mathrm{hr} 71$ hour & $43.8 \mu \mathrm{g}$ & 87.46 & 3.44 & 9.1 & 87.7 & 2.2 & 10.1 \\
\hline avg & $42.6 \mu \mathrm{g}$ & $87.33 \pm 0.13$ & $2.68 \pm 0.82$ & $10.05 \pm 0.95$ & $87.4 \pm 0.30$ & $2.1 \pm 0.16$ & $10.6 \pm 0.45$ \\
\hline $4 \mu \mathrm{g} / \mathrm{hr} 72$ hour & $46.6 \mu \mathrm{g}$ & 80.19 & 1.98 & 17.84 & 79.7 & 2.3 & 18.0 \\
\hline $4 \mu \mathrm{g} / \mathrm{hr} 72$ hour & $48.3 \mu \mathrm{g}$ & 84.77 & 2.19 & 13.05 & 84.3 & 2.6 & 13.0 \\
\hline avg & $47.5 \mu \mathrm{g}$ & $82.48 \pm 2.29$ & $2.09 \pm 0.10$ & $15.45 \pm 2.40$ & $81.9 \pm 2.30$ & $2.5 \pm 0.16$ & $15.5 \pm 2.50$ \\
\hline $2 \mu \mathrm{g} / \mathrm{hr} 92$ hour & $62.5 \mu \mathrm{g}$ & 90.27 & 2.38 & 7.35 & 89.6 & 2.0 & 8.4 \\
\hline $8 \mu \mathrm{g} / \mathrm{hr} 120$ hour & $59.7 \mu \mathrm{g}$ & 83.02 & 4.38 & 12.6 & 82.7 & 3.2 & 14.1 \\
\hline
\end{tabular}

The same DNA distribution data were reanalyzed using the Multicycle program. Cellcycle S\% for control and $48 \mathrm{hr}-28 \mu \mathrm{g}$ total STSP-treated animals were $3.6 \pm 0.2 \%$ and $3.3 \pm 0.3 \%$ respectively, compared with $2.9 \pm 0.3 \%$ and $3.0 \pm 0.3 \%$ produced by Multicycle analysis. Multicycle analysis produced a slightly lower S\% value compared with Cellcycle. Reanalysis 
with the Multicycle program produced similar G1\% results as well compared with the Cellcycle program. G1\% of the control population analyzed by Cellcycle was $88 \pm 3 \%$ compared with $88 \pm 3 \%$ analyzed with Multicycle. Comparison of data from $48 \mathrm{hr}-28 \mu \mathrm{g}$ total STSP treated animals using the two programs produced no differences in $\mathrm{G} 1 \%, 86 \pm 4 \%$ vs $86 \pm 4 \%$, Cellcycle vs Multicycle program .

G1, S, and G2+M\% of control BM cells examined in this study, Table 4, were $74 \pm 0.8 \%$, $18 \pm 2 \%$, and $8.5 \pm 1.8 \%$, respectively. The experimental groups all appeared to average lower G1\% and higher S\% compared with control values. The S\% for the $47 \mathrm{hr}-28 \mu \mathrm{g}$ total treated animal was $25 \pm 0.5 \%$ and $S \%$ for the $71 \mathrm{hr}-47 \mu \mathrm{g}$ total treated animal was $30 \pm 7 \%$. There was no significant difference between the Cellcycle and Multicycle program analyses, except for the expected decreased S\% observed with Multicycle.

Table 4. Bone Marrow Cell DNA Distribution Analyzed Using Cellcycle and Multicycle Programs. (Average values are given in $\% \pm S E M$ ).

\begin{tabular}{|c|c|c|c|c|c|c|c|}
\hline & \multirow[b]{2}{*}{ Total dose } & \multicolumn{3}{|c|}{ Cellcycle } & \multirow[b]{2}{*}{ G 1} & \multicolumn{2}{|c|}{$\begin{array}{l}\text { Multicycle } \\
\text { (all Ist order) }\end{array}$} \\
\hline & & G 1 & $\mathbf{S}$ & $\mathbf{G} 2+\mathbf{M}$ & & $\mathbf{S}$ & $\mathbf{G} 2+\mathbf{M}$ \\
\hline Control 1 & - & 72.5 & 16.7 & 10.8 & 74.0 & 16.5 & 9.5 \\
\hline Control 2 & - & 73.6 & 21.3 & 5.1 & 73.9 & 15.9 & 10.2 \\
\hline Control 3 & - & 75.1 & 15.2 & 9.7 & 74.7 & 14.6 & 10.8 \\
\hline avg & - & $73.7 \pm 0.8$ & $17.7 \pm 1.8$ & $8.5 \pm 1.7$ & $74.2 \pm 0.3$ & $15.7 \pm 0.6$ & $10.2 \pm 0.4$ \\
\hline $2 \mu \mathrm{g} / \mathrm{hr} 47$ hour & $26.5 \mu \mathrm{g}$ & 58.9 & 24.6 & 16.5 & 59.1 & 22.3 & 18.6 \\
\hline $2 \mu \mathrm{g} / \mathrm{hr} 47$ hour & $31.3 \mu \mathrm{g}$ & 58.9 & 25.5 & 15.6 & 58.7 & 24.1 & 17.2 \\
\hline avg & $28.9 \mu \mathrm{g}$ & $58.9 \pm 0.2$ & $25.1 \pm 0.5$ & $16.0 \pm 0.5$ & $58.9 \pm 0.2$ & $23.2 \pm 0.9$ & $17.9 \pm 0.7$ \\
\hline $2 \mu \mathrm{g} / \mathrm{hr} 71$ hour & $41.4 \mu \mathrm{g}$ & 61.8 & 22.5 & 15.8 & 61.8 & 21.0 & 17.2 \\
\hline $2 \mu \mathrm{g} / \mathrm{hr} 71$ hour & $43.8 \mu \mathrm{g}$ & 47.8 & 37.2 & 15.0 & 48.8 & 32.2 & 19.1 \\
\hline avg & $42.6 \mu \mathrm{g}$ & $54.8 \pm 7.0$ & $29.8 \pm 7.4$ & $15.4 \pm 0.4$ & $55.3 \pm 6.5$ & $26.6 \pm 5.6$ & $18.2 \pm 1.0$ \\
\hline $4 \mu \mathrm{g} / \mathrm{hr} 72$ hour & $46.6 \mu \mathrm{g}$ & 64.8 & 28.1 & 7.1 & 65.9 & 22.3 & 11.7 \\
\hline $4 \mu \mathrm{g} / \mathrm{hr} 72$ hour & $48.3 \mu \mathrm{g}$ & 71.4 & 21.0 & 7.6 & 71.9 & 17.5 & 10.6 \\
\hline avg & $47.5 \mu \mathrm{g}$ & $68.1 \pm 3.3$ & $24.6 \pm 3.5$ & $7.4 \pm 0.3$ & $68.9 \pm 3.0$ & $19.9 \pm 2.4$ & $11.2 \pm 0.6$ \\
\hline $2 \mu g / h r 92$ hour & $62.5 \mu \mathrm{g}$ & 72.3 & 21.1 & 6.6 & 72.8 & 16.4 & 10.8 \\
\hline $4 \mu \mathrm{g} / \mathrm{hr} 120$ hour & $59.7 \mu \mathrm{g}$ & 61.3 & 26.9 & 11.8 & 61.9 & 23.0 & 15.1 \\
\hline
\end{tabular}

A limited analysis of thymocytes and splenocytes was performed in the above experiments, Tables 5 and 6, respectively. There was no evidence of G1 arrest in either of these body compartments. S\% of thymocytes in control and experimental samples were $4.9 \%$ and 4.2\% respectively. As in bone marrow cells, splenocytes from the experimental group appeared 
to show a slightly higher $\mathrm{S} \%$ than the control group, $2.7 \%$ vs $4.3 \%$ and did not show evidence of G1 arrest.

Table 5. Thymocyte (THY) DNA Distribution Analyzed Using Cellcycle and Multicycle programs. (Average values are given in $\% \pm$ SEM).

\begin{tabular}{|c|c|c|c|c|c|c|}
\hline & \multicolumn{4}{|c|}{ Cellcycle } & \multicolumn{2}{|c|}{$\begin{array}{c}\text { Multicycle } \\
\text { (all Ist order) }\end{array}$} \\
\hline & G 1 & $\mathbf{S}$ & $\mathrm{G} 2+\mathrm{M}$ & G 1 & $\mathbf{S}$ & $\mathrm{G} 2+\mathrm{M}$ \\
\hline Control 1 & 82.6 & 5.4 & 12.0 & 81.7 & 5.8 & 12.5 \\
\hline Control 2 & 87.6 & 5.8 & 6.7 & 87.7 & 9.0 & 3.3 \\
\hline Control 3 & 83.5 & 3.4 & 13.1 & 84.8 & 5.4 & 9.7 \\
\hline avg & 84.6 & 4.9 & 10.6 & 84.7 & 6.7 & 8.5 \\
\hline $4 \mu \mathrm{g} / \mathrm{hr} 72$ hour & 82.2 & 3.7 & 14.1 & 82.5 & 3.2 & 14.3 \\
\hline $4 \mu \mathrm{g} / \mathrm{hr} 72$ hour & 56.8 & 4.7 & 38.4 & 93.7 & 3.4 & 2.9 \\
\hline avg & 84.5 & 4.2 & 11.3 & 88.1 & 3.3 & ] 8.6 \\
\hline $2 \mu \mathrm{g} / \mathrm{hr} 92$ hour & 81.1 & 4.2 & 14.7 & 80.0 & 5.1 & 14.8 \\
\hline
\end{tabular}

Table 6. Splenocyte (SPL) DNA Distributions Analyzed Using Cellcycle and Multicycle Programs. (Average values given in \% SEM).

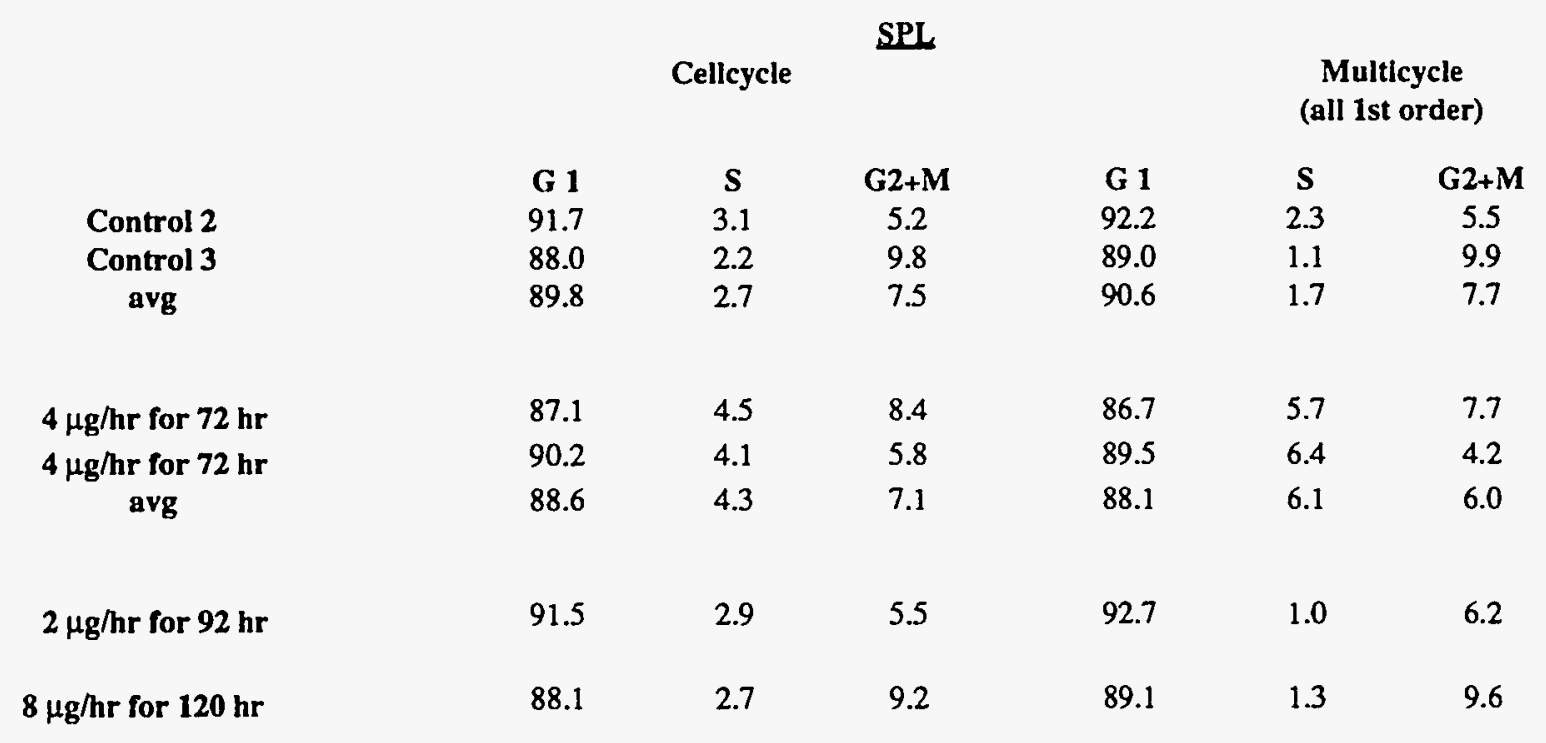

\section{Study Series III}

Alveolar macrophages (AM) cultured in the presence of rmGM-CSF increased $\sim 20-30$ fold in number as of day 7 , Figure 2 . The average total number of AM at day 7 was $\sim 2.4 \times 10^{5}$ cells for the control group. The addition of $1 \mathrm{ng} / \mathrm{mL}$ of STSP to the culture medium eliminated 
this proliferative response, Figure 2. The average day 7 number of AM cultured in STSP was $\sim 9.0 \times 10^{3}$ cells, a value which was similar to the number of AM initially seeded onto the culture wells $\left(10^{4}\right)$. The above averages were obtained from three individual experiments performed in triplicate.

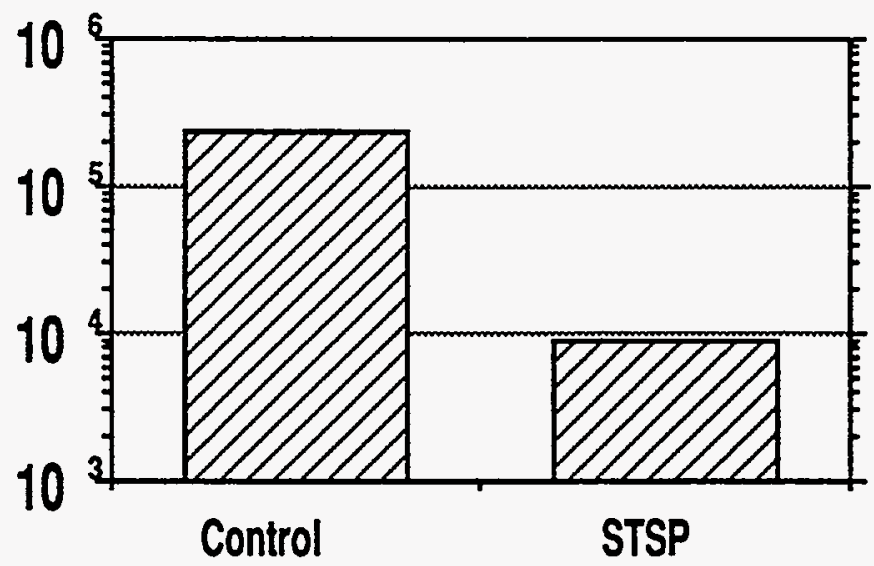

Figure 2. Total number of alveolar macrophages (AM) at day 7. AM were initially seeded at 1 x $10^{4}$ cells/well. Control: $0.5 \mathrm{ng} / \mathrm{mL}$ rmGM-CSF only. STSP: $1 \mathrm{ng} / \mathrm{mL}+$ rmGM-CSF.

Bone marrow cells cultured in 40\% L929/60\% $\alpha$ MEM increased in number $\sim 12$ fold at day 21 , Figure 3. The average total number of bone marrow cells at day 21 was $1.2 \times 10^{5}$ for the control group. The addition of $1 \mathrm{ng} / \mathrm{mL}$ of STSP to the culture medium substantially diminished this proliferative response. Average day 21 number of bone marrow cells cultured in STSP was $3.1 \times 10^{4}$ cells. BM cells were seeded at $10^{4}$ cells/well. The above averages were obtained from two individual experiments done in triplicate.

Evidence from our in vitro studies of the effect of STSP on rat AM and BM show that STSP indeed does exert an anti-proliferative effect on primary rat AM and BM cells. Also, vehicles used to solubilize STSP, PEG and DMSO did not show any antiproliferative effects (data not shown). 


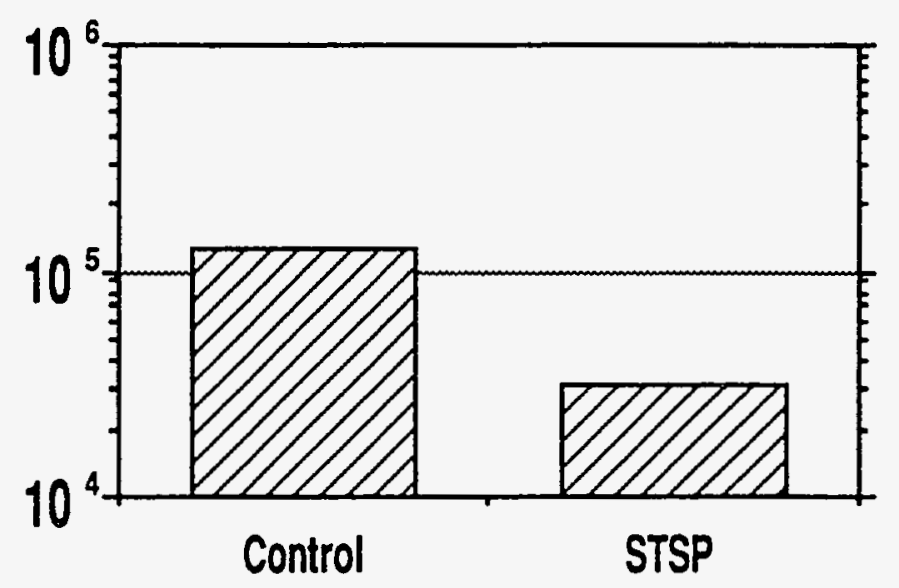

Figure 3. Total number of bone marrow cells at day 7. BM were seeded at $1 \times 10^{4}$. Control: 40\% L929 cell-conditioned media. STSP: $1 \mathrm{ng} / \mathrm{mL}+40 \%$ L929 cell-conditioned medium.

\section{Study Series IV}

Slide sections and histochemical staining of the sample tissues were prepared by Veritas Laboratories. Sections of duodenum and pancreas from control and study group animals were analyzed for BrdU labeled nuclei. Among experimental STSP-diet animals, there was a $100 \%$ survival rate in both rats ( $n=8$ total), at day 4 , and mice $(n=8)$ at days 5 and 10 . Estimated total masses of STSP consumed by the rats in this study ranged between $778 \mu \mathrm{g}$ and $842 \mu \mathrm{g}$. Estimated total masses of STSP consumed by the mice ranged between $233 \mu \mathrm{g}$ and $282 \mu \mathrm{g}$ for 5 days of treatment and $517 \mu \mathrm{g}$ and $538 \mu \mathrm{g}$ for 10 days of treatment.

Control rats $(n=8)$ receiving i.p. injections of PBS and study group rats $(n=8)$ receiving daily $100 \mu \mathrm{L}(100 \mu \mathrm{g})$ i.p injections of STSP survived 7 days, Table 7. Rats $(\mathrm{n}=2)$ receiving daily $250 \mu \mathrm{L}(250 \mu \mathrm{g})$ i.p. injections of STSP died after day 2 injections, Table 7. 
Table 7. Injection Profiles for STSP-Treated Rats.

$\begin{array}{ccccc}\mathbf{N} & \text { [STSPI/dav }(u g) & \text { TotaLSTSPL(ug) } & \text { Day } & \text { Comments } \\ 8 & - & - & 7 & \text { control } \\ 4 & 100 & 400 & 4 & \text { survived } \\ 4 & 100 & 700 & 7 & \text { survived } \\ 2 & 250 & 500 & 3 & \text { died on day 3 }\end{array}$

All control group $(n=10)$ mice that received daily $100 \mu \mathrm{L}$ i.p. injections of PEG:dextrose $/ \mathrm{H}_{2}$ O.survived to day 12 . Mice $(\mathrm{n}=4)$ receiving daily $100 \mu \mathrm{L}(100 \mu \mathrm{g})$ STSP injections died at day 4. The mice that received daily i.p. injections of $25 \mu \mathrm{g}$ of STSP survived to day 12 , Table 8 .

Table 8. Injection profile for STSP-Treated Mice.

$\begin{array}{ccccc}\mathbf{N} & \text { [STSP]/day (ug) } & \text { Total[STSPI(ug) } & \text { Day } & \text { Comments } \\ 10 & - & - & 4,7,10,12 & \text { control } \\ 4 & 100 & 400 & 4 & \text { died on day 4 } \\ 4 & 25 & 100 & 4 & \text { survived } \\ 4 & 25 & 175 & 7 & \text { survived } \\ 4 & 25 & 250 & 10 & \text { survived } \\ 8 & 25 & 300 & 12 & \text { survived }\end{array}$

Light microscopic examinations of the gastro-intestinal sections for BrdU incorporation revealed positive staining for both control and study group animals. To label the proliferating cell population, a $25 \mathrm{mg}$ i.p. injection of BrdU was administered for $4 \mathrm{hr}$ before sacrifice. However, one study group $(n=2)$ receiving $25 \mu \mathrm{g}$ STSP/day for 12 days showed a labeling pattern that differed from that of the control group. In this case, there was evidence of negative staining in the microvilli and crypt cells of the GI tract, and some cells appeared to have undergone changes consistent with necrosis, i.e., pycnotic nuclei, loss of continuous cell membranes. However, we were not able to reproduce these results in a subsequent study that was performed in an identical manner.

\section{Study Series $V$}

Animals receiving a $7.1 \mu \mathrm{g}$ bolus injection of STSP followed by the continuous infusion of STSP at a rate of $6.54 \mathrm{ng} / \mathrm{mL}$ were sacrificed at 24 and $48 \mathrm{hrs}$ post-treatment. AM and BM 
were analyzed using the flow cytometer after mithramycin staining. 24 hour treated animals $(\mathrm{n}=2)$ recorded $\mathrm{G} 1, \mathrm{~S}$ and $\mathrm{G} 2+\mathrm{M} \%$ of $\sim 70,26$ and $4 \%$ respectively. 48 hour treated animals $(n=2)$ recorded $G 1, S$ and $G 2+M \%$ of $\sim 72,24$ and $4 \%$ respectively. It should be noted that some technical difficulties were encountered with the constant infusions in this initial study; it is unclear that all of the animals received suitable infusions. As well, technical difficulties were encountered with the DNA analyses. Thus, our first attempt at using the new pharmacokinetic data to establish appropriate drug treatment regimens was unsuccessful.

\section{Summary/Discussion}

The effects of STSP in vitro to selectively arrest normal non-transformed cells in G1 at very low concentrations while arresting transformed cells at a much higher concentration led to our attempt to produce a condition of STSP-induced G1 arrest in vivo. The goal of the in vivo experiments, accordingly, was to achieve a GI arrest of normal cells in the BM, lung or the GI tract compartment using the rat and mice models. BM cells, AM, thymocytes and splenocytes were harvested from control and STSP-treated animals and their DNA distributions were quantitated by flow cytometry. Gastrointestinal sections from STSP treated animals were labeled with BrdU and immunohistochemically assayed as well. In a complete G1 arrested cell population, we would expect to observe a higher than nnormal G1 percent with a corresponding very low or zero $\mathrm{S} \%$.

\section{Study Series I}

Dosimetry for the bolus and continuous i.v. infusion rates of STSP was based on a general pharmacokinetic model, using widely ranging assumptions about the volume of distribution of STSP in the body as well as its potential rate(s) of elimination from the body. The BM cells were initially targeted because of their high proliferation rate, and because they are oftentimes a collateral target site of some types of cancer therapy. The i.v infusion route was selected because we assumed that a continuous concentration of STSP was needed to effectively arrest normal cells in vivo. The femur BM cells were harvested from various STSP-treated and control animals, and their DNA distributions were analyzed using flow cytometry after staining with mithramycin. No important differences between control cells and cells from STSP-treated animals were observed in terms of their DNA distributions at 24, 48 and 72 hrs after initiation of treatment. Thus, the widely ranging treatment regimens used in this study component did not bring about a condition of G1 arrest in the BM compartment. Additionally, we found that relatively high doses of STSP were lethal. Even at doses that caused death, there was no evidence of $\mathrm{G} 1$ arrest. 


\section{Study Series II}

Background evidence from Study Series I suggested that STSP administered i.v. did not reach the tissue compartment of interest, i.e., BM cells. Assuming that the dose or concentration of STSP diminished in the Series I studies as the drug traveled from the site of administration, we hypothesized that a greater concentration would be present more proximal to the point of infusion. Therefore, we additionally examined alveolar macrophages (AM) lavaged from the lungs of treated animals. We also continued to analyze BM cells, and we initiated thymocyte and splenocyte analyses as well to investigate the effects of STSP in other body compartments.

We assumed that cells in the lung would be arrested in G1, and we examined this possibility by assessing the DNA distributions in AM from STSP-treated rats in that the AM reside in the alveolar sacs. However, in order for the AM to be arrested in $G 1$, we recognized that the STSP would have to penetrate across endothelial cells that line the alveolar capillaries and further translocate across the epithelial lining of the alveoli.

No evidence was obtained to suggest that the continuous infusion of STSP over a range of infusion rates resulted in a condition of $\mathrm{G} 1$ arrest in any of the populations of cells examined, regardless of the program used to analyze the DNA distributions.

Animal death was observed at the highest STSP dosages of 10 and $20 \mu \mathrm{g} / \mathrm{hr}(480$ and 960 $\mu \mathrm{g}$ total); the animals so treated $(\mathrm{n}=2)$ did not survive through day 2 .

\section{Study Series III}

In vitro studies were performed using lavaged $\mathrm{AM}$ and femur $\mathrm{BM}$ cells to verify that STSP can indeed exert an antiproliferative effect with rat cells. AM cultured in the presence of rmGM-CSF, a promitogenic cytokine, increased $\sim 20-30$ fold in total cell number at day 7 . In contrast, AM cultured in the presence of $1 \mathrm{ng} / \mathrm{mL}$ STSP, along with ImGM-CSF, showed no evidence of proliferation. This confirms the antiproliferative effects of STSP on these ratderived target cells. Also, AM cultured in the presence of dimethyl sulfoxide (DMSO) or PEG, along with rmGM-CSF, increased $\sim 10$ fold in total cell number at day 7 (data not shown); DMSO and PEG were the solvents used in making stock solutions of STSP.

Similar results were obtained from femur BM cells in culture. They exhibited a $\sim 12$ fold growth at the end of 3 weeks in culture in L929 supernatant supplemented media. BM cells grown in the presence of STSP showed a far lesser proliferative response. This observation confirms the anti-proliferative effects of STSP on rat bone marrow target cells. The carrier vehicles PEG and DMSO did not exhibit any antiproliferative effects on the cells in vitro. 


\section{Study Series IV}

The GI tract is composed of an inherently high proliferating cell population. By using the thymidine analog BrdU to label the proliferative activity of these cells in vivo, we could easily detect any cell cycle arresting activity of STSP with an immunohistochemical assay. By contrast, the pancreas is composed of non-cycling cells and was used as a negative control tissue. We experimented with different routes of STSP administration to attempt to increase the effective dose at the target tissue site. STSP was incorporated into food to potentially increase the gastrointestinal tract's exposure to STSP and possibly to decrease the toxic, systemic effects of the drug. I.P. injection of STSP was also used as a possible means to increase the exposure of STSP. In rats, STSP i.p. injections at the highest concentrations $(250 \mu \mathrm{g} / \mathrm{day})$ were lethal by day 3. In mice, concentrations of $100 \mu \mathrm{g} /$ day were lethal by day 4. STSP administered by i.p. injection was not effective in inducing a G1 arrest in the intestinal samples; visual examination of immunohistologically developed slides revealed no cell cycle arresting activity, i.e., the cells were labeled with BrdU. One study group, however, did exhibit $\sim 90 \%$ negative staining. Compared with the control slides, the study group slides showed some necrosis along the length of the microvilli, indicating a possible cytotoxic effect from STSP treatment. Unfortunately, we were unable to reproduce the results in a subsequent study performed in an identical manner.

We additionally conducted an immunohistochemical assay with bone marrow cells harvested from mice receiving i.p. injections of STSP and control solutions. Upon examination by fluorescence microscopy, both cell populations were visually identified as positive for BrdU incorporation. Based on these observations, we must conclude that $\mathrm{G} 1$ arrest was not induced in the gastrointestinal tract or the bone marrow of mice that received i.p. injections of STSP.

\section{Study Series $V$}

A new set of experiments has been initiated, based on newly obtained pharmacokinetic data concerning the behavior of STSP administered to the blood compartment. The technical procedures being used in these experiments are the same as those used in the previous bolus/i.v. infusion studies. Briefly, a bolus injection of STSP is administered to establish a theoretical baseline concentration of STSP in the blood, i.e., nominally $10 \mathrm{ng} / \mathrm{mL}$, and STSP is infused at a mass concentration rate to sustain this concentration over a $72 \mathrm{hr}$ period. In addition to sampling bone marrow cells for DNA distribution analyses, blood is also being sampled from the animals to verify STSP concentration during the course of therapy.

Applying the new values for the apparent volume of distribution of STSP into the pharmacokinetic model to dose regimens used in previous studies (I and II) suggests that the blood concentrations of STSP in our previous studies were higher, and usually much higher than the $1-10 \mathrm{ng} / \mathrm{mL}$ concentration needed to bring about a condition of G1 arrest and suggests 
infusion rates were much higher than the present infusion rate employed in the new Study Series $\mathrm{V}$ experiments.

Based on the new pharmacokinetic data, estimates of the STSP blood concentrations that may have been achieved in previous experiments (Study Series I and II) are shown in Table 9.

Table 9. Estimates of STSP Blood Concentrations Achieved in Prior Experiments (Series I and II Studies).

\begin{tabular}{|c|c|c|}
\hline Bolus Injection & $\begin{array}{c}\text { Infusion Rate Used } \\
\text { mass } / \mathrm{hr}\end{array}$ & $\begin{array}{l}\text { Estimated Blood } \\
\text { Concentration of } \\
\text { STSP }\end{array}$ \\
\hline $\begin{array}{l}55 \mathrm{ng} \\
1.9 \mu \mathrm{g} \\
19 \mu \mathrm{g} \\
125 \mu \mathrm{g} \\
175 \mu \mathrm{g} \\
200 \mu \mathrm{g}\end{array}$ & $\begin{array}{l}19 \mathrm{ng} \\
329 \mathrm{ng} \\
3.3 \mu \mathrm{g} \\
7.2 \mu \mathrm{g} \\
10 \mu \mathrm{g} \\
17 \mu \mathrm{g}\end{array}$ & $\begin{array}{l}14.4 \mathrm{ng} / \mathrm{mL} \\
249 \mathrm{ng} / \mathrm{mL} \\
2.5 \mu \mathrm{g} / \mathrm{mL} \\
5.5 \mu \mathrm{g} / \mathrm{mL} \\
7.7 \mu \mathrm{g} / \mathrm{mL} \\
12.9 \mu \mathrm{g} / \mathrm{mL}\end{array}$ \\
\hline Bolus Injection & $\begin{array}{c}\text { Infusion Rate Used } \\
\text { mass } / \mathrm{hr}\end{array}$ & $\begin{array}{l}\text { Estimated Blood } \\
\text { Concentration of } \\
\text { STSP }\end{array}$ \\
\hline $\begin{array}{l}0 \\
0 \\
0\end{array}$ & $\begin{array}{l}4 \mu \mathrm{g} \\
8 \mu \mathrm{g} \\
16 \mu \mathrm{g}\end{array}$ & $\begin{array}{l}1.5 \mu \mathrm{g} / \mathrm{mL} \\
3.0 \mu \mathrm{g} / \mathrm{mL} \\
6.0 \mu \mathrm{g} / \mathrm{mL}\end{array}$ \\
\hline
\end{tabular}

\section{Conclusions to Date}

No firm evidence has been obtained as yet to suggest that STSP can bring about a state G1 arrest in vivo. There are a variety of explanations that may explain our negative findings. 1). The STSP may not have reached the compartments of interest by the dosing routes used. 2). Adequate STSP concentrations achieved at the compartments of interest may have been inadequate, i.e., $<1 \mathrm{ng} / \mathrm{mL}$. 3). The concentrations of STSP achieved at the compartments of interest may have been excessive, thereby halting cells in their cell cyle stage at the time of initiation of STSP treatment.

While the recently obtained new pharmacokinetic data about the behavior of STSP in the blood compartment has provided insight into developing optimal dose regimens, further studies in this area are required. Specifically, information is needed regarding the apparent volume of distribution of STSP when administered at much lower bolus concentration, and the kinetics of 
removal of lower blood concentrations of STSP must be determined to ensure that our previous findings are applicable to lower dosing strategies. STSP's major drawback so far has been its detrimental side effects that in some studies have resulted in animal deaths. This should not be a problem in future studies in which lesser amounts of STSP will be used.

From Study Series III results, we may conclude that PEG and DMSO, carrier vehicles for STSP, do not have an anti-proliferative effect on the target cells and that they would not be expected to result in cell cycle changes in vivo. 


\section{References}

1. Boltz-Nitulescu, G., Wiltschke, C., Holzinger, C., Fellinger, A., Scheiner, O., Gessl, A., and Forster, O. (1987) Differentiation of rat bone marrow cells into macrophages under the influence of mouse L929 cell supernatant. J. Leuk. Biol. 41:83-91.

2. Buchholz, R.A., Dundore, R. L., Cumiskey, W. R., Harris, A. L., and Silver, P.J. (1991) Protein kinase inhibitors and blood pressure control in spontaneously hypertensive rats. Hypertension 17:91-100.

3. Crissman, H., Gadbois, D., Tobey, R., and Bradbury, E.M. (1991) Transformed mammalian cells are deficient in kinase-mediated control of progression through the G1 phase of the cell cycle. Proc. Natl. Acad. Sci. USA 88: 7580-7584.

4. Dean, P.N., and Jett, J. H. (1974) Mathematical analysis of DNA distributions derived from flow microfluorometry. J. Cell Biol. 60:523-527.

5. Fallon, R.J. (1990) Staurosporine inhibits a tyrosine protein kinase in human hepatoma cell membranes. Biochem. Biophys. Res. Commun. 170:1191-1196.

6. Furukawa, KI., Tawada, Y. and Shigekawa, M. (1989) Protein kinase C activation stimulates plasma membrane $\mathrm{Ca}^{++}$pump in cultured vascular smooth muscle cells. J. Biol. Chem. 264:4844-4849.

7. Gurley, L.R., Umbarger, K.O., Kim, J.M., Bradbury, E.M., and Lehnert, B.E. (1994) Staurosporine analysis and its pharmacokinetics in the blood of rats. Los Alamos National Laboratory Report LA-12788-MS, Office of Scientific and Technical Information, Oak Ridge, TN, July, 1994.

8. Hayes, B. E., and Will, J.A. (1978) Pulmonary artery catheterization in the rat. American Physiological Society. H452-H454.

9. Herbert, J.M., Daviet, I., and Maffrand, J.P. (1991) Characterization of extracellular binding sites for [3H]-staurosporine on capillary endothelial cells. Cell Biol. Int. Rep. 15:883-890.

10. Holm, A., and Cram, S. (1973) An improved flow microfluorometer for rapid measurements of cell fluorescence. Exp. Cell Res. 80:105-110, 1973.

11. Jett, J.H. (1991) Some considerations in the analysis of clinical DNA histogram data. In Flow Cytometry and Image Analysis for Clinical Applications. I. Nishiya, L. S. Cram, and J. W. Gray, editors. Elsevier Science Publishers B. V., Amsterdam. 157-167.

12. Lehnert, BE., Valdez, Y.E., and Tietjen, G.L. (1989) Alveolar macrophage-particle relationships during lung clearance. Am.J. Respir. Cell Mol. Biol. 1:145-154.

13. Morioka, H., Ishihara, M., Shibai, H., and Suzuki, T. (1985) Staurosporine-induced differentiation in a human neuroblastoma cell line, NB-1. Agric. Biol. Chem. 49:1959-1963.

14. Nakano, H., Kobayashi, E., Takahashi, I., Tamaoki, T., Kuzuu, Y., and Iba, H. (1987) Staurosporine inhibits tyrosine-specific protein kinase activity of rous sarcoma virus transforming protein p60. J. Antibiotics 40:706-708. 
15. Niggli, V. and Keller, H. (1991) On the role of protein kinases in regulating neutrophil actin association with the cytoskeleton. J. Biol. Chem. 266:7927-7932.

16. Omura, S., Iwai, Y., Hirano, A., Nakagawa, , Awaya J., Tsuchiya, H., Takahashi, Y., and Mausma, R. (1977) A new alkaloid AM-2282 of Streptomyces origin taxonomy, fermentaion, isolation and preliminary characterization. J. Antibiot. 3(4), 275-282.

17. Secrest, R. J., Williams, P., Bonjouklian, R., Modlin, D., Firman, K., Turk, J., and Cohen, M. L. (1991) Hypotensive properties of the protein kinase inhibitor, staurosporine, in normotensive and spontaneously hypertensive rats. Clin. and Exper. Hyper.-Theory and Practice A13(2), 219234.

18. Stavert, D.M., Wilson, J.S., and Lehnert, B.E. (1987) Post-catheterization support strategies for studies involving instrumented rats to assess work performance degradation following the inhalation of toxic substances. 1987 Annual Meeting of the Society of Toxicology, February 1987, Washington D.C., The Toxicologist 7:802.

19. Tamaoki, T., Nomoto, H., Takahashi, I., Kato, Y., Morimoto, M., and Tomita, F. (1986) Staurosporine, a potent inhibitor of phospholipid/ $\mathrm{Ca}^{++}$dependent protein kinase. Biochem. Biophys. Res. Commun. 135:397-402.

20. Umbarger, K.O., Kim, J.M., Lehnert, B. E., Bradbury, E.M., and Gurley, L.R. (1993) Analysis of staurosporine (STSP) in blood: sequestration of STSP in erythrocytes. Annual Meeting of the Society of Toxicology Meeting, March 1993, New Orleans, The Toxicologist 13:1480. 